\title{
Komunikasi Interpersonal Tenaga Kerja Indonesia dan Anak
}

\section{Interpersonal Communication of Indonesian Workers and Children}

\author{
Rehia Karenina Isabella Barus ${ }^{1)}$, Salamiah Sari Dewi2) \& Khairuddin ${ }^{2)}$ \\ 1)Program Studi Ilmu Komunikasi, Fakultas Ilmu Sosial dan Ilmu Politik \\ Universitas Medan Area, Indonesia \\ 2) Fakultas Psikologi, Universitas Medan Area, Indonesia
}

Diterima: 27 Agustus 2020; Direview: 24 Oktober 2020; Disetujui: 10 November 2020

*Coresponding Email: Rehia@ staff.uma.ac.id; salamiahsaridewi@gmail.com; khairuddin@staff.uma.ac.id

\begin{abstract}
Abstrak
Studi ini berfokus pada Komunikasi Interpersonal Anak Tenaga Kerja Indonesia dengan Orangtuanya. Studi ini dilatarbelakangi bahwa realitas permasalahan komunikasi yang dialami oleh anak-anak yang orangutanya bekerja sebagai tenaga kerja Indonesia di luar negeri. Hubungan anak dan orangtua kemudian terjembatani dengan adanya media teknologi komunikasi seperti telepon selular dan media social. Tujuan penelitian ini adalah untuk mengetahui hambatan, bentuk perhatian dan proses Komunikasi Interpersonal Anak dengan orang tua. Penelitian ini menggunakan metode penelitian deskriptif kualitatatif. Temuan kajian ini mengindikasikan bahwa Pertama: Lemahnya komunikasi interpersonal anak dengan orangtuanya dikarenakan koneksi teknologi komunikasi yang sering terputus juga kesibukan orang tuanya sehingga jaranag dapat berkomunikasi dengan anak. Hambatan lain adalah makna interpersonal kurang karena gesture dan ekspresi yang tidak diketanhui karena komunikasi yang tidak langsung; Kedua: Orang tua memperhatikan kondisi anak namun tidak secara detail sehingga kerap terjadi pelanggaran yang dilakukan oleh anak-anak; Ketiga: Bentuk pesan berupa pertanyaan tertutup menyebabkan kurangnya feedback yng mengurangi kedinamisan percakapan orang tua dan anak.

Kata Kunci: Komunikasi Interpersonal, Tenaga Kerja Indonesia, Anak
\end{abstract}

\begin{abstract}
This study focuses on the Interpersonal Communication of Children of Indonesian Workers with Their Parents. This study is motivated by the reality of communication problems experienced by children whose parents work as Indonesian workers abroad. The relationship between children and parents is then bridged by the presence of communication technology media such as cellular phones and social media. The purpose of this study was to determine 1) Barriers to interpersonal communication between children and parents; 2) Form of parental attention to children; 3) Interpersonal Communication Process of Children and Parents. This study uses the findings of this study to indicate that First: The weakness of interpersonal communication between children and their parents is due to communication technology connections that are often cut off as well as their parents' busyness so that the network can communicate with children. Another obstacle is the lack of interpersonal meaning due to gestures and expressions that are not recognized because of indirect communication; Second: Parents pay attention to the condition of the child, but not in detail so that violations are often committed by children; Third: The form of the message in the form of closed questions causes a lack of feedback which reduces the dynamics of the conversation between parents and children.
\end{abstract}

Keywords: Interpersonal; Communication; Indonesian Workers; Children

How to Cite: Barus, R.K.I. Dewi, S.S. \& Khairuddin (2020). Komunikasi Interpersonal Tenaga Kerja Indonesia dan Anak. Journal of Education, Humaniora and Social Sciences (JEHSS). 3 (2): 369-376. 


\section{PENDAHULUAN}

Peran orang tua dalam mendidik anak dimulai dari mengajarkan norma-norma. Norma dalam keluarga sangat berperan sebagai pegangan anak ketika mereka berinteraksi dengan anggota keluarga dan juga lingkungannya. Idealnya peran anggota keluarga adalah ayah mencari nafkah, ibu mengurus rumah dan anak-anak bersekolah. Orang tua kemudian akan bertugas lagi untuk menjaga dan melindungi seluruh anggota keluarganya dalam satu tempat tinggal yang sama. Ideal sebuah keluarga di atas ternyata tidak dapat dinikmati oleh banyak keluarga di Indonesia, salah satunya adalah mereka yang bekerja sebagai buruh migran atau tenaga kerja Indonesia di luar negeri.

Buruh migran merupakan pekerja yang bekerja di luar negeri. Undang-Undang No. 39 Tahun 2004 menyatakan bahwa Tenaga Kerja Indonesia (TKI) adalah setiap warga negara Indonesia yang memenuhi syarat untuk bekerja di luar negeri dalam hubungan kerja untuk jangka waktu tertentu dengan menerima upah. Kurangnya pendidikan sehingga kemudian mendapatkan upah yang rendah di negara asal merupakan alasan mereka untuk merantau bekerja di luar negeri. Indonesia adalah salah satu negara di Asia pengirim TKI terbanyak ke negara-negara lain, termasuk di dalamnya TKI yang berasal dari provinsi Sumatera Utara untuk ditempatkan di beberapa sektor usaha.

Dari tabel 1 ini menunjukkan bahwa di wilayah Sumatera, penempatan TKI yang paling banyak berasal dari daerah Sumatera Utara sebanyak 1.718 di Tahun 2015 dan 2084 di tahun 2016, terjadi peningkatan yang signifikan sekali dari berbagai kabupaten/kota, sedangkan penempatan TKI yang paling sedikit berasal dari daerah Bengkulu dan Aceh. Hal tersebut menggambarkan bahwa kondisi ketenagakerjaan di Indonesia masih belum maksimal dari segi penyediaan lapangan pekerjaan, sehingga mendorong TKI mengambil keputusan mencari pekerjaan di negara lain karena perbedaan tingkat upah. Untuk lebih jelasnya dapat dilihat pada tabel 1 berikut ini.

Tabel 1

Penempatan Tenaga Kerja Luar Negeri Berdasarkan Provinsi di Sumatera Periode 2016 (Januari-Februari)

\begin{tabular}{llll}
\hline No & Asal Daerah & $\mathbf{2 0 1 5}$ & $\mathbf{2 0 1 6}$ \\
\hline & & Jan-Feb & Jan-Feb \\
\hline $\mathbf{1}$ & Aceh & 93 & $\mathbf{2 5}$ \\
\hline $\mathbf{2}$ & Kepulauan Riau & 134 & 109 \\
\hline $\mathbf{3}$ & Riau & $\mathbf{1 1 7}$ & 99 \\
\hline 5 & Sumatera Utara & 1718 & $\mathbf{2 0 8 4}$ \\
\hline 6 & Sumatera Barat & 93 & $\mathbf{1 2 5}$ \\
\hline 7 & Jambi & 93 & 97 \\
\hline
\end{tabular}

Sumber: BNP2TKI, 2017

Studi ini mengkaji hubungan interpersonal yang dilakukan oleh orang tua dengan anaknya. Arena dan konteks kajian yang dibahas terutama diarahkan pada orang tua yang bekerja sebagai seorang tenaga kerja di luar negeri dengan anak-anaknya yang berada di Indonesia. Adapun latarbelakang kajian bahwa realitas permasalahan yang dialami oleh orang tua yang bekerja sebagai seorang Tenaga Kerja Indonesia begitu kompleks, rumit dan masih menyimpan berbagai persoalan yang harus diatasi. Persoalan tersebut termanifestasikan dalam berbagai bentuk, yaitu gaji, overstay, putus hubungan komunikasi, kekerasan dari majikan, pekerjaan yang tidak sesuai dengan perjanjian kerja.

Komunikasi interpersonal rutin orang tua dengan anak sebenarnya adalah sesuatu yang wajib dikarenakan komunikasi keluarga dasar utama dalam membentuk hubungan anak dengan

http://mahesainstitute.web.id/ojs2/index.php/jehss nahesainstitut@gmail.com 
lingkungan lain di luar keluarganya. Komunikasi interpersonal menjadi sarana orang tua memberikan pengajaran kepada anaknya, sehingga akan menciptakan rasa aman dan nyaman pada anak. Komunikasi interpersonal yang baik dalam keluarga merupakan salah satu dasar terciptanya generasi muda yang baik (Napitupulu et al., 2017; Ritonga et al., 2016).

Proses komunikasi sekarang ini sangat terbantu dengan majunya teknologi media baru. Harga gadget yang semakin murah dan dibarengi dengan semakin murahnya harga kuota internet membuat sekarang semakin gampang untuk berkomunikasi dengan siapa saja dan dimana saja. Kemurahan dan kemudahan di atas juga dibarengi dengan semakin berkembangnya perkembangan fitur pada gadget. Gadget memiliki fitur yang beragam dimana media baru mampu dengan cepat mendekatkan yang jauh, bahkan media baru memungkinkan kita untuk berbicara face to face dengan anak dan keluarga kita yang berada di belahan dunia manapun melalui aplikasi video conference. Kemudahan ini akan mampu menciptakan rasa dekat dari anak terhadap orang tuanya sehingga anak juga akan merasa terlindungi.

Rasa dekat dan keteraturan komunikasi dengan orang tua akan memberikan kontrol terhadap anak untuk tidak terjerumus pada kenakalan maupun kejahatan. Hasil kajian yang dilakukan oleh Restialovi ${ }^{3}$ tentang ragam kenakalan anak apa saja yang dilakukan oleh anakanak TKI ada yang bersifat ringan seperti merokok, membolos, juga ada kenakalan anak yang bersifat berat yaitu kebut-kebutan, miras (minum-minuman keras), penyalahgunaan obatobatan terlarang (narkoba) dan lain sebagainya.

Kejahatan-kejahatan di atas tidak hanya dipicu oleh kurangnya komunikasi dengan orang tua juga karena kurangnya perhatian dari wali dimana anak dititipkan. Wali anak buruh migran adalah seseorang yang tidak jarang memiliki anggota keluarga yang juga harus dirawat. Bertambahnya anak yang harus dididik dan dirawat akan menambah beban terhadap keluarganya. Tidak jarang, anak buruh migran yang dititipkan diterlantarkan, kurang dididik, kurang diperhatikan, karena merasa bukan kewajibannya sebagai orang tua si anak.

Anak-anak tidak hannya melakukan kenakalan, anak-anak dapat juga mengalami kejahatan. Informasi Direktur LP3TP2A Kabupaten Malang4, Hikmah Bafaqih, bahwa terdapat 348 anak buruh migran dari Desa Matraman, Kedungsalam, dan Purwodadi, Kecamatan Donomulyo yang perlu didamping karena mengalami kejahatan dan ironisnya, beberapa dari mereka mendapat pelecehan seksual dari orang-orang terdekatnya dalam hal ini wali tempat mereka berlindung.

Kenakalan dan kejahatan terhadap anak di atas harusnya memberikan kesadaran bahwa kita harus menjaga dan memperhatikan anak-anak. UNICEF mendefinisikan anak sebagai penduduk yang berusia antara 0 sampai dengan 18 tahun. Undang-Undang RI Nomor 4 tahun 1979 tentang Kesejahteraan Anak, menyebutkan bahwa anak adalah mereka yang belum berusia 21 tahun dan belum menikah ${ }^{5}$. Menurut Undang-undang no 23 tahun 2002 tentang perlindungan anak6, hak anak adalah bagian dari hak asasi manusia yang wajib dijamin, dilindungi dan dipenuhi oleh orangtua, masyarakat, pemerintah dan negara.

Berdasarkan fenomena-fenomena di atas dapat diketahui bahwa perlindungan anak dimulai dengan berkomunikasi secara teratur dan dalam bentuk interpersonal dengan anak. Komunikasi akan memberikan keleluasaan anak untuk mengadu, bertukar pikiran tentang kejadian yang terjadi pada diri mereka setiap hari. Komunikasi juga akan menjadi alat orang tua dalam memberikan nasehat dan juga teguran terhadap anak.

Permasalahan jarak dan waktu bahkan mahalnya biaya berkomunikasi harusnya tidak lagi menjadi kendala bagi orang tua dan anak. Gadget berbiaya murah dengan fitur yang canggih menjadi solusi dalam mengikis permasalahan tersebut. Dimanapun juga untuk dapat berkomunikasi, karena sudah diselesaikan oleh adanya gadget dan fitur-fiturnya. Berdasarkan fenomena di atas sangat menarik kemudian untuk melihat bagaimana komunikasi interpersonal 
yang dilakukan oleh orang tua dalam hal ini tenaga kerja Indonesia di luar negeri dengan anaknya yang berada di Indonesia.

\section{METODOLOGI PENELITIAN}

Penelitian ini menggunakan metode kualitatif deskriptif. Teknik pengumpulan data menggunakan observasi, wawancara (Teknik Indepth Interview), dan dokumentasi. Penentuan informan penelitian dengan menggunakan purposive sampling (pemilihan informan berdasarkan ciriciri tertentu). Kriteria khusus agar informan yang diambil nanti sesuai dengan tujuan penelitian itu sendiri dan dapat memecahkan masalah serta memberikan nilai yang lebih representatif, sehingga tehnik yang diambil dapat memenuhi objektif dilakukannya suatu penelitian. Informan pada kajian ini yaitu keluarga TKW yang bekerja di luar negeri dan mempunyai anak, yang terdiri dari: 1) Anak dari TKI; 2) Kakek dan nenek; 3) Saudara kandung; 4) Wali lainnya. Untuk analisis keabsahan data penulis menggunakan metode triangulasi dimana pada tahap ini dilakukan jika data atau informasi yang diperoleh dari subjek atau informan penelitian diragukan kebenarannya. ${ }^{9}$ Lokasi penelitian dilakukan di Kelurahan Bantan Timur, Kecamatan Medan Tembung Kota Medan, karena penduduk kelurahan ini khususnya ibu rumah tangga banyak yang bekerja ke luar negeri.

Landasan berpikir dalam penelitian ini nanti akan menggunakan teori komunikasi interpersonal sehingga tujuan akhirnya adalah dengan pisau analisis teori ini bisa mengungkapkan fenomena komunikasi dalam keluarga Tenaga Kerja Indonesia (TKI)

DeVito menyebutkan bahwa komunikasi interpersonal adalah komunikasi antara dua orang atau di antara orang-orang dalam kelompok kecil. Solomon dan Theiss ${ }^{8}$ menyebutkan bahwa komunikasi interpersonal lebih spesifik mengarah pada komunikasi yang muncul antara orang-orang dan menciptkan ikatan personal di antara mereka.

Dalam gambar berikut ini, Solomon dan Theiss menjelaskan lebih detail defenisi interpersonal.

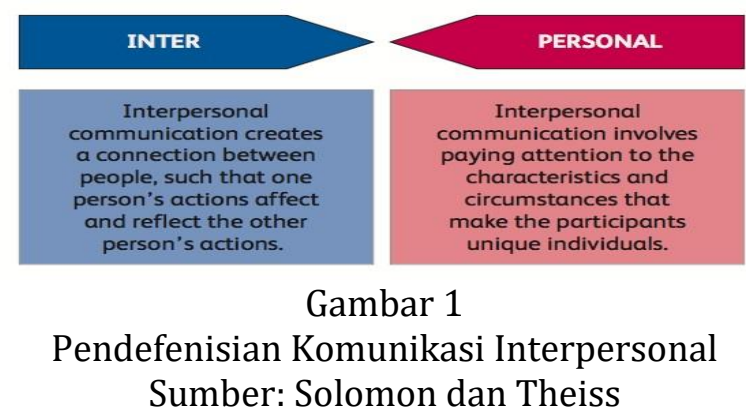

Dari gambar 1 tersebut disebutkan bahwa kata "inter" menekankan bahwa komunikasi interpersonal menghubungkan manusia. Sementara kata "personal" menunjukkan bahwa kualitas personal seseorang sangat penting dalam komunikasi interpersonal.

Lebih lanjut, Solomon dan Theiss memaparkan beberapa karakteristik komunikasi interpersonal, yaitu: Komunikasi interpersonal adalah proses yang berkelanjutan; Pertukaran terus-menerus terjadi dalam komunikasi interpersonal. Bahkan dalam kondisi diam mendengarkan, seseorang sedang mengirim pesan yang disampaikan kepada lawan bicara sehingga dapat menjadi patokan bagi orang lain dalam berkomunikasi; Komunikasi interpersonal adalah proses yang dinamis.

Hal ini terjadi karena makna berubah dan berkembang seiring waktu. Pesan yang disampaikan di masa lalu dapat mempengaruhi bagaimana pesan diciptakan dan dimaknai di masa yang akan datang. 
Komunikasi interpersonal memiliki konsekwensi. Hal tersebut bermakna bahwa ada hasil dari setiap aktivitas komunikasi interpersonal. Konsekwensi yang didapat dapat berupa hal diinginkan atau yang tidak diinginkan serta memiliki beragam bentuk.

Komunikasi interpersonal tidak dapat ditarik lagi. Pesan yng sudah disampaikan tidak dapat ditarik kembali, begitupun seseorang tidak dapat menciptakan kembali kesempatan berkomunikasi yang sudah terlewatkan. Semua pesan yang telah disampaikan akan menjadi bagian dari ingatan bersama di antara orang-orang yang terlibat dalam komunikasi interpersonal (Suharyanto et al., 2017; Thariq et al., 2017).

Komunikasi interpersonal tidak sempurna. Dalam berkomunikasi dipergunakan simbolsimbol untuk menyampaikan pesan. Dalam memaknai simbol tersebut, terkadang terjadi perbedaan antara orang-orang yang terlibat dalam komunikasi interpersonal. Kecenderungan yang terjadi dalam komunikasi interpersonal adalah bahwa orang-orang yang terlibat merasa bahwa setiap orang memiliki pemaknaan yang sama terhadap simbol-simbol tersebut. Hal inilah yang dapat menjadi penghalang dalam berkomunikasi.

\section{HASIL DAN PEMBAHASAN \\ Hambatan dalam Komunikasi}

Permasalahan ekonomi yang semakin tinggi merupakan alasan utama para Tenaga Kerja Indonesia untuk pergi merantau mengejar rejeki ke negeri lain. Kesenjangan gaji yang diterima antara bekerja di dalam dan di luar negeri adalah salah satu pertimbagan mereka untuk bekerja di Malaysia, Taiwan bahkan Timur Tengah. Ketika permasalahan ekonomi dapat diselesaikan maka yang terjadi adalah anak-anak dititipkan ke orang lain sehingga sering terjadi kenakalan bahkan kejahatan karena kurangnya perhatian dari orang tua. Kurangnya komunikasi tersebut sekarang dapat diatasi melalui penggunaan gadget baik dalam bentuk video conference maupun media sosial.

Mayoritas orang tua yang menjadi TKI di Kelurahan Bantan Timur bekerja di Malaysia dan Taiwan sebagai asisten rumah tangga, buruh pabrik dan pekerja bangunan. Sebagian besar dari pekerja adalah si ibu dan kedua orang tua. Hanya sedikit ayah yang bekerja sebagai TKI. Untuk keluarga yang kedua orang tuanya menajdi TKI, anak-anak rata-rata dititip di rumah nenek atau bibi.

Ketika orang tua jauh, maka ia akan berusaha untuk mengetahui bagaimana kondisi dan perkembangan anaknya. Ini akan mengurangi rasa khawatir dan memberikan efek tenang dalam melakukan pekerjaannya. Namun perpisahan yang lama akan memberikan efek kerenggangan dalam ikatan hubungan orang tua dan anak. Ini dapat menyebabka miskomunikasi dan juga permasalahan identitas diri pada anak. Ini terjadi pada komunikasi interpersonal orang tua dan anak pada penelitian ini.

Kesibukan orang tua dan koneksi jaringan komunikasi menjadi alasan orang tua jarang menanyakan kondisi dari anak. Komunikasi intens terjadi di awal ketika orang tua tiba di daerah kerjanya. Lama-kelamaan kuantitas komunikasi menjadi berkurang karena kesibukan orang tuanya. Anak-anak juga menjawab bahwa ketika mereka sedang bercengkerama dengan akrab dengan orang tuanya, dalam ini memaparkan permasalahan dan juga kegiatan anak akan sering terputus oleh masalah koneksi atau juga karena orang tua dipanggil oleh atasan atau majikannya.

Komunikasi interpersonal dengan media ini dirasa anak-anak tidak efektif karena pesan yang disampaikan dan tersampaikan tidak efektif. Selain karena masalah keterbatasan waktu dan jaringan, anak-anak juga merasa kurang puas karena kedekatan dan kehangatan dengan orang tuanya tidak dirasakan. Ketidakmampuan menangkap gesture dan ekspresi orang tuanya menciptakan jarak dan ketidakakraban anak dalam berkomunikasi.Sehingga kadang 
komunikator dan komunikan kurang bisa memahami maksud yang diinginkan dalam komunikasi tersebut.

\section{Bentuk Perhatian Orang Tua}

Anak-anak menjawab bahwa kebanyakan orang tua bertanya tentang pendidikan anak namun pertanyaan juga tidak ditanyakan secara detail, seperti tidak ditanyakannya permasalahan anak di sekolah, atau siapa guru wali, siapa teman sebangku, pelajaran apa yang tidak dipahami. Pertanyaan hanya sekedar bagaimana sekolah. Ketika dijawab anak :"Baik", maka orang tua tidak bertanya lebih lanjut. Demikian juga tentang keingintahuan orang tua terkait kesehatan dan pergaulan anak-anaknya. Orang tua hanya bertanya sekadarnya saja. Orang tua jarang bertanya tentang kegiatan anak sehari-hari. Gaya komunikasi yang digunakan orang tua di sini adalah gaya komunikasi pasif dimana komunikator menghidari cara mengungkapkan pendapat atau perasaan, secara terbuka, tentang berbagai hal, dan juga menghindari konfrontasi dengan anaknya. Gaya komunikasi lahir dari rasa bersalah karena telah meninggalkan anaknya.

Penelitian ini mendapatkan data bahwa orang tua sangat jarang memarahi anak-anaknya baik itu terkait nilai sekolah yang jelek, atau karena kenakalan-kenakalan yang dilakukan anaknya.

Liliweri menyatakan bahwa orang tua yang bersikap seperti ini akan mengakibatkan: Gagal bersikap tegas terhadap anaknya; Secara sengaja atau tidak sengaja memberikan peluang bagi anak untuk melanggar hak-hak mereka; Miskin kontak dengan anaknya.

Hal di atas kemudian tercermin dari tingkah laku anak yang didapat dari penelitian ini, antara lain adalah Anak-anak jarang bertanya tentang kondisi; orang tuanya; Anak-anak jarang melaporkan kegiatannya kepada orang tua; Anak-anak tidak terbuka akan permasalahannya; Anak-anak tidak meminta pendapat orangtuanya ketika memutuskan sesuatu.

\section{Proses Komunikasi Interpersonal Orang Tua dan anak}

Komunikasi yang bersifat dinamis adalah ketika terjadi proses saling memberi dan menerima informasi diantara pihak-pihak yang melakukan komunikasi. Dalam hal ini seharusnya terjadi komunikasi yang intens dan berkelanjutan antara orang tua. Komunikasi yang intens akan dapat mempengaruhi komunikan kita.

Hasil penelitian menunjukkan bahwa kebanyakan komunikasi yang terjadi cenderung datar dan tidak berkesinambungan. Dimana orang tua bertanya dan dijawab seadanya oleh anak. Tidak terdapat ketertarikan yang ditunjukkan dalam intonasi maupun penggunaan katakata yang membujuk dan menunjukkan kerinduan dalam percakapan. Orang tua bertanya dengan nada datar, dan dijawab oleh si anak dengan nada datar juga.

Hal ini mungkin juga dipengaruhi oleh usia anak yang menjadi informan kebanyakan berusia 10-12 tahun. Prilaku sosial anak-anak usia 10-12 tahun sangat dipengaruhi oleh orangorang di sekitarnya. Pada masa ini anak-anak cenderung menyukai kegiatan bermain yang dilakukan secara berkelompok, anak-anak juga memiliki teman-teman sebaya untuk melakukan kegiatan bersama. Anak-anak merasa senang dan perlu untuk bersama-sama, sehingga berkeinginan selalu ada di tengah-tengah kelompoknya, Rita Eka Izzaty, dkk, (2008). Anak-anak tersebut akan merasa sangat terganggu akan kegiatan sosialnya karena ada telepon dari orang tuanya.

Komunikasi interpersonal adalah proses yang berkelanjutan, Komunikasi yang dilakukan oleh orang tua harusnya dilaksanakan secara terus menerus dimana pesan yang dikirim harusnya mendapatkan feed back dari komunikator dan komunikan. Feed back ini kemudian menjadi patokan untuk pesan selanjutnya yang ingin dijawab atau ditanya oleh masing-masing pelaku. Feed back juga dipicu oleh tingkat keingintahuan terhadap pemahaman maupun kondisi 
dari si komunikan sehingga kemudian terjadi kesesuain paham antara komunikan dan komunikator.

Pada kasus TKI dan anak dalam kajian ini, kebanyakan informan menjawab bahwa tingkat keingintahuan orang tua terhadap kondisi anak tidak terlalu tinggi. Percakapan yang dilakukan cenderung menggunakan pertanyaan tertutup yang ketika dijawab tidak memiliki peluang untuk pertanyaan selanjutnya. Orang tua juga jarang mendengarkan setiap keluh kesah anak, padahal melalui keluh kesah anak maka ini akan membentuk karakter anak untuk lebih nyaman dan percaya diri terhadap apa yang dilaluinya. Oleh karena itu, perasan anak untuk bila selalu didengarkan keluh kesahnya akan memberikan ruang nyaman dan tetap semangat terhadap psikologis anak

Hasil penelitian di atas menunjukkan bahwa proses komunikasi interpersonal adalah proses yang berkelanjutan tidak terlaksana. Salah satu pemicunya adalah bentuk pertanyaan dari orang tua yang bersifat tertutup sehingga tidak dapat menggali permasalahan yang dihadapi seorang anak.

\section{SIMPULAN}

Komunikasi interpersonal orang tua dan anak sering terhambat karena adanya kesibukan orang tua dan juga koneksi teknologi komunikasi. Selain itu juga makna interpersonal terhalang karena tidak diketahuinya gesture dan ekspresi pelaku komunikasi. Ada perhatian orang tua terhadap kondisi anak namun tidak dilakukan secara detail sehingga memberi peluang pelanggaran dilakukan oleh anak. Proses komunikasi interpersonal tidak terjadi secara dinamis dan berkesinambungan karena intonasi berbicara yang datar dan mengunakan pertanyaan tertutup sehingga tidak dapat mengembangkan percakapan.

\section{DAFTAR PUSTAKA}

DeVito, J.A. (2015). The Interpersonal Communication Book 14th Edition. United States of America: Pearson Education, Inc

https://programpeduli.org/berita/dialog-bersama-lp3tp2a-untuk-anak-buruh-migran. diakses Januari 2018.

Huraerah, A. (2006). Kekerasan Pada Anak. Bandung: Penerbit Nuansa

Liliweri, A. (2015).Komunikasi Antar Personal. Jakarta: Kencana Prenadamedia Group

Mudjia, R. (2018), Triangulasi dalam Penelitian Kualitatif.n.d. http://mudjiarahardjo.com/artikel diakses Januari, 2018

Napitupulu. M.A. Hasibuan, E.J. \& Hidayat, T.W. (2017). Persepsi Tenaga Kerja Indonesia Terhadap Gaya Komunikasi Instruktur dalam Memberikan Pembekalan Materi. PERSPEKTIF, 6 (1): 13-17.

Portal. bnp2tki.go.id.. Data Penempatan Tenaga Kerja Luar Negeri Berdasarkan Provinsi di Sumatera Periode 2016 (Januari-Februari) http://portal.bnp2tki.go.id/uploads/data/data_08-022017_111324_Data-P2TKI_tahun_2016.pdf diakses Januari 2018

programpeduli.org. Dialog Bersama LP3TP2A untuk Anak Buruh Migran.

Restialovi, A.F. (2015). Ragam Kenakalan Anak Yang Orang Tuanya Bekerja Sebagai TKI (Tenaga Kerja Indonesia) Keluar Negeri Di Desa Balesono Kecamatan Ngunut Kabupaten Tulungagung. Skripsi.Program Studi Pendidikan Pancasila dan Kewarganegaraan, Jurusan Hukum dan Kewarganegaraan, Fakultas Ilmu Sosial, Universitas Negeri Malang.

Ritonga, S.A. dan Effiati J.H, (2016), Komunikasi Interpersonal Guru dan Siswa dalam Mengembangkan Bakat dan Kreativitas Anak Autis di SLB Taman Pendidikan Islam (TPI) Medan, Jurnal Simbolika: Research and Learning in Comunication Study. 2 (2): 188-199

Solomon, D, dan Theiss, J. (2013). Interpersonal Communication: Putting Theory into Practice. New York: Routledge

Suharyanto, A. Matondang, A. Walhidayat, T. (2017). The Interpersonal Communication of the Chinese Ethnic Families in Cheng Beng Ceremony in Medan, Indonesia. IOSR Journal Of Humanities And Social Science (IOSR-JHSS), 22(12)Ver.4:38-44. 
Rehia Karenina Isabella Barus, Salamiah Sari Dewi \& Khairuddin, Komunikasi Interpersonal Tenaga Kerja Indonesia dan Anak

Thariq, M. (2017), Membangun Ketahanan Keluarga Dengan Komunikasi Interpersonal, Jurnal Simbolika: Research and Learning in Comunication Study, 3 (1): 34-44.

Undang-Undang Nomor 23 tahun 2002 tentang Perlindungan Anak

Undang-Undang Nomor 39 Tahun 2004 tentang Penempatan dan Perlindungan Tenaga Kerja Indonesia di Luar Negeri 